\title{
AN INSIGHT INTO IN VITRO BIOACTIVITY OF WILD-GROWING PUFFBALL SPECIES LYCOPERDON PERLATUM (PERS) 1796
}

\author{
Aleksandra R. Novaković ${ }^{*}$, Maja A. Karaman², Milan N. Matavulj², Boris M. Pejin ${ }^{3}$, \\ Miona M. Belović ${ }^{1}$, Tanja I. Radusin ${ }^{1}$, Nebojša M. Ilić ${ }^{1}$ \\ ${ }^{1}$ University of Novi Sad, Institute of Food Technology, Bulevar cara Lazara 1, 21000 Novi Sad, \\ Serbia \\ ${ }^{2}$ University of Novi Sad, Faculty of Sciences, Department of Biology and Ecology, Trg Dositeja \\ Obradovića 3, 21000 Novi Sad, Serbia \\ ${ }^{3}$ University of Belgrade, Institute for Multidisciplinary Research (IMSI), Department of Life Sciences, \\ Kneza Višeslava 1, 11030 Belgrade, Serbia
}

\author{
${ }^{*}$ Corresponding author: \\ Phone: +381214853770 \\ Fax: +38121450725 \\ E-mail address: aleksandra.novakovic@fins.uns.ac.rs
}

\begin{abstract}
Lycoperdon perlatum (Pers) 1796 is saprobic puffball species with a global distribution. It is edible if young, when the gleba is still homogeneous and white. Since this species has a pleasant texture and taste, it has been used in soups as a substitute for dumplings. The aim of this work was to study bioactivity of crude extracts prepared from wild-growing sporocarps of $L$. perlatum collected from Eastern Serbia during 2012.

The bioactivity screens included antioxidant (DPPH ${ }^{\circ}$ and FRAP assays), antiproliferative (human breast MCF-7 cancer cell-line; MTT and SRB assays) and antibacterial (three referent ATCC strains; microdilution assay) effects. Polar extracts (aqueous - LycAq and ethanol - LycEtOH) and a nonpolar extract (hexane - LycHex) of the examined mushroom species were screened. In addition, LycAq and LycEtOH were primarily characterized by UV-VIS spectrophotometry, due to determination of chemical composition (total phenol and flavonoid contents).

The highest anti-DPPH radical activity was observed for $\mathrm{LycAq}\left(\mathrm{IC}_{50}=46.56 \mu \mathrm{g} / \mathrm{ml}\right)$. In comparison with LycAq, less polar LycEtOH showed slightly better ferric reducing antioxidant power (FRAP) $\left(\mathrm{IC}_{50}=21.87 \mu \mathrm{g} / \mathrm{ml}\right.$ and $\mathrm{IC}_{50}=19.28 \mu \mathrm{g} / \mathrm{ml}$, respectively $)$. However, total phenol contents of both extracts were similar $(\approx 2.0 \mathrm{mg} \mathrm{GAE} / \mathrm{g}$ d.w. $)$. Conversely, modest activities were found against Staphylococcus aureus ATCC 25922 (LycHex, MIC $=3.12 \mathrm{mg} / \mathrm{ml}$ ) and MCF-7 cells (with the highest one obtained for LycEtOH after $72 \mathrm{~h}, \mathrm{IC}_{50}=367.54 \mu \mathrm{g} / \mathrm{ml}$ and $\mathrm{IC}_{50}=390.03 \mu \mathrm{g} / \mathrm{ml}, \mathrm{MTT}$ and SRB assays, respectively).

According to the obtained experimental data, L. perlatum can be considered as a good source of novel and potent natural antioxidants for use in regular diet.
\end{abstract}

Keywords: puffball, Lycoperdon perlatum, biological activity, natural antioxidants, medicinal food

\section{INTRODUCTION}

Since the ancient times, mushrooms have been valued by humankind as a culinary wonder and traditional medicine. Recently, it has been discovered that many fungal species, including puffballs, represent miniature pharmaceutical factories producing hundreds of natural products with potent and broad range bioactivities. Furthermore, these organisms have a long history of use in Oriental medicine, supported by contemporary studies (Miles and Chang, 2004).

Production of reactive oxygen and nitrogen species occurs during normal cell metabolism. The excess of free radicals leads to oxidative stress, resulting in oxidative DNA damage, implicated in the pathogenesis of numerous disorders, such 
as cardiovascular, atherosclerosis, rheumatoid arthritis and cancer (De Silva et al, 2013).

On the other hand, antibiotic resistance has become a global concern (Westh et al., 2004). The clinical efficacy of many existing antibiotics is being threatened by the emergence of multidrug resistant pathogens (Bandow et al., 2003). The increasing failure of chemotherapeutics has led to the screening of a number of medicinal mushrooms for their antimicrobial potential (Karaman et al., 2009a; Karaman et al., 2014; Nwachukwu and Uzoeto, 2010; Ozen et al., 2011; Alves et al., 2013).

Mushrooms are believed to be a very good source of nutraceuticals, mainly with antioxidant, antiproliferative and antimicrobial properties (Wasser, 2002; Barros et al., 2008a; Karaman et al., 2009a; Ferreira et al., 2009; Cheung, 2010; Karaman et al., 2010; De Silva et al, 2012; Patel et al., 2012; De Silva et al, 2013; Heleno et el., 2014). Lycoperdon perlatum (Pers) 1796 is a species of puffball fungus from the family Agaricaceae. This saprobic organism grows solitarily, scattered, or in groups or clusters on the ground. It can also grow in fairy rings (Dickinson and Lucas, 1982). Several chemicals have been identified in its fruit bodies such as sterol derivatives $((S)$-23-hydroxylanostrol, ergosterol a-endoperoxide, ergosterol 9,11dehydroendoperoxide and (23E)-lanosta8,23-dien-3 $\beta, 25$-diol), volatile compounds (3-octanone, 1-octen-3-ol and (Z)-3-octen1-ol) and an unusual amino acid such as lycoperdic acid (Lamotte et al., 1978; Szumny et al., 2010). The puffball extracts are known for exhibiting antibacterial activity against human pathogens such as Bacillus subtilis, Escherichia coli, Staphylococcus aureus and Pseudomonas aeruginosa, with efficiency comparable to that of the antibiotic ampicillin (Ramesh and Pattar, 2010). Moreover, antifungal activities against Candida albicans, C. tropicalis, Aspergillus fumigates and Alternaria solani have been also reported (Pujolet et al., 1990).

This study, focusing on in vitro bioactivity evaluation of autochthonous $L$. perlatum, included antioxidant, antiproliferative and antibacterial screens. To the best of our knowledge, this is the first report on bioactive properties of $L$. perlatum originating from Serbia.

\section{MATERIAL AND METHODS}

\section{Chemicals}

Folin-Ciocalteu (FC) reagent, anhydrous sodium carbonate, gallic acid (GA), aluminium trichloride hexahydrate, sodium acetate trihydrate, quercetin hydrate, 2,2-diphenyl-1-picrylhydrazyl (DPPH•), anhydrous iron(III) chloride, 2,4,6-Tris(2-pyridyl)-s-triazine (TPTZ), 2-thiobarbitu-ric acid, disodium hydrogen phosphate, thiazolyl blue tetrazolium bromide, phenazine methosulfate (PMS), $\beta$-nicotinamide adenine dinucleotide (NADH), 3-(4,5-dimethylthiazole-2-yl)-2,5-diphenylte-trazolium bromide (MTT), dimethyl sulfoxide (DMSO), sulfurhodamine $B$ (SRB) and trichloroacetic acid (TCA) were purchased from Sigma-Aldrich (Steinheim, Germany). Dulbecco's Modified Eagle's Medium with $4.5 \%$ of glucose (DMEM) and fetal calf serum (FCS) were obtained from PAA Laboratories (Pasching, Austria).

\section{Puffball samples}

Lycoperdon perlatum (Pers) 1796 was collected in Sikole area (a village near the Negotin town, Serbia) during 2012. After its identification, a voucher specimen (MYC12-00664) was deposited at the Herbarium BUNS, University of Novi Sad, Serbia. The puffball samples were frozen at $-20{ }^{\circ} \mathrm{C}$, prior to freeze-drying procedure (Bio alpha, Martin Christ $\mathrm{GmbH}$, Germany). Freeze dried samples were ground to a fine powder, wrapped in plastic bags and stored in a dark place at room temperature, until further use.

\section{Extraction}

The processed sporocarps of $L$. perlatum $(10 \mathrm{~g})$ were extracted with distilled water $(\mathrm{Aq})$, ethanol $(\mathrm{EtOH})$ and hexane $(\mathrm{Hex})$ for $24 \mathrm{~h}$, on a shaker (Thermo Fisher Scientific, USA; $120 \mathrm{rpm}$ ) at room temperature $\left(25^{\circ} \mathrm{C}\right)$. The extracts were filtered through filter paper (Whatman No. 4). The organic solvents (EtOH and Hex) were removed by rotary evaporator at $40{ }^{\circ} \mathrm{C}$ (Büchi, Switzerland), while the aqueous extract (LycAq) was freeze-dried. The obtained extracts (ethanol - LycEtOH and hexane - 
LycHex) and water-LycAq were stored at $+4{ }^{\circ} \mathrm{C}$ and $-20{ }^{\circ} \mathrm{C}$, respectively. The relevant dried residues were redissolved in $5 \%$ DMSO, prior to analysis.

\section{Total phenol content}

Total phenol (TP) content of LycEtOH and LycAq was determined according to method by Singleton et al. (1999), adapted for a 96-well plate reader (Multiskan Ascent, Thermo Electron Corporation). Folin-Ciocalteu reagent $(125 \mu \mathrm{l}, 0.1 \mathrm{M})$ was added to diluted extracts $(25 \mu \mathrm{l})$. After 10 min, $100 \mu \mathrm{l}$ of $7.5 \% \mathrm{w} / \mathrm{v}$ sodium carbonate was added and the reaction mixture was incubated for $2 \mathrm{~h}$. Absorbance was read at $690 \mathrm{~nm}$. TP is expressed as mg gallic acid equivalents (GAE)/g of dry weight (d.w.).

\section{Total flavonoid content}

Total flavonoid (TF) content of LycEtOH and LycAq was measured spectrophotometrically, in a 96-well plate reader, using a modified method by Chang et al. (2002). The relevant sample $(30 \mu \mathrm{l})$ was mixed with methanol $(90 \mu \mathrm{l})$, aluminiumtrichloride $(6 \mu \mathrm{l}, 0.75 \mathrm{M})$, sodium acetate $(6 \mu \mathrm{l}, 1 \mathrm{M})$ and distilled aqua $(170 \mu \mathrm{l})$. Absorbance was measured at $414 \mathrm{~nm}$, after incubation of $30 \mathrm{~min}$. The results are expressed as $\mathrm{mg}$ quercetin equivalents (QE)/g of dry weight (d.w.).

\section{DPPH' scavenging activity}

DPPH' scavenging activity was evaluated according to method by Espin et al. (2000). The reaction mixture consisted of sample $(10 \mu \mathrm{l})$, DPPH solution $(60 \mu \mathrm{l})$ and methanol $(180 \mu \mathrm{l})$. After incubation of 60 min (dark place, at room temperature), absorbance was measured at $540 \mathrm{~nm}$. Each sample was tested at five different concentrations (60 - $800 \mu \mathrm{g} / \mathrm{ml}$, LycEtOH; 15-1000 $\mu \mathrm{g} / \mathrm{ml}$, LycAq). The results are expressed as $\mathrm{IC}_{50}$ values.

\section{Ferric reducing antioxidant power (FRAP)}

FRAP assay was performed according to a modified procedure of Benzie and Strain (1999). The FRAP reagent consisted of $300 \mathrm{mM}$ acetate buffer $(\mathrm{pH}=3.6), 10 \mathrm{mM}$ TPTZ in $40 \mathrm{mM} \mathrm{HCl}$ and $20 \mathrm{mM} \mathrm{FeCl}_{3}$, in the ratio 10:1:1 (v:v:v). The sample $(10 \mu \mathrm{l})$, FRAP reagent $(225 \mu \mathrm{l})$ and distilled aqua $(22.5 \mu \mathrm{l})$ were added in a 96 -well plate.
Absorbance was measured at $620 \mathrm{~nm}$, after incubation of $6 \mathrm{~min}$. The results are expressed as mg ascorbic acid equivalents (AAE)/g of dry weight (d.w.).

\section{Antibacterial activity}

LycHex was the only extract screened for antibacterial activity at in vitro conditions, after dissolving in 5\% DMSO, to reach a final concentration of $0.5 \%(\mathrm{w} / \mathrm{v}) \quad(\mathrm{CLSI}$ procedure, 2008; slightly modified by Karaman et al., 2009b). Standard American Type Culture Collection (ATCC) strains of two Gram-positive bacteria, namely $S$. aureus ATCC 25922 and $B$. subtilis ATCC 6633, and one Gram-negative bacterium, namely E. coli ATCC 25923, were used. Two-fold microdilution assay in 96-well microplates (Spektar, Čačak, Serbia) was applied for determination of minimal inhibitory and bactericidal concentrations (MIC and $\mathrm{MBC}$, respectively). Pure bacterial strains were subcultured on nutrient agar slants at $37^{\circ} \mathrm{C}$ for $24 \mathrm{~h}$; their suspensions corresponding to McFarland 0.5 optical density, $\approx 1.5 \times 10^{8} \mathrm{CFU} / \mathrm{ml}$. The extract concentration ranged from 0.78 to 25.00 $\mathrm{mg} / \mathrm{ml}$. After incubation at $35^{\circ} \mathrm{C}$ for $18-24$ $\mathrm{h}, \mathrm{MIC}$ and $\mathrm{MBC}$ were determined. Last two wells served as a growth control (positive control) and negative control (5\% DMSO), respectively. The reference antibiotics (gentamicin and ampicillin) were applied as control standards.

\section{Antiproliferative activity}

Cells

Estrogen dependent MCF-7 cells were grown in DMEM (PAA Laboratories) supplemented with $10 \%$ FCS. The cells were seeded in a 96-well microplate (5000 cells per well). After incubation of $24 \mathrm{~h}$, the growth medium was replaced with $100 \mu \mathrm{l}$ of medium containing the examined samples (extracts) at four different concentrations $(33.3 \mu \mathrm{g} / \mathrm{ml}, 100.0 \mu \mathrm{g} / \mathrm{ml}, 300.0$ $\mu \mathrm{g} / \mathrm{ml}$ and $900.0 \mu \mathrm{g} / \mathrm{ml})$. The untreated cells served as the control, while pure DMSO was used as a positive control. The growth of MCF-7 cells was evaluated by standard colorimetric assays, MTT and SRB.

\section{MTT Assay}

After incubation of $24 \mathrm{~h}$ and $72 \mathrm{~h}$ respecttively, the cell viability was determined by 
the proliferation MTT assay (Mosmann, 1983). This assay is based on the color reaction of mitochondrial dehydrogenase in living cells with MTT reagent. Upon the incubation, MTT reagent was added to each well $\left(50 \mu \mathrm{g} / 100 \mu \mathrm{l} / \mathrm{well}\right.$; at $37{ }^{\circ} \mathrm{C}$, in $5 \% \mathrm{CO}_{2}$, for $3 \mathrm{~h}$ ). The crystals of produced formazan were dissolved in $100 \mu \mathrm{l}$ acidified isopropanol $(0.04 \mathrm{M} \mathrm{HCl}$ in isopropanol). Absorbance was measured at 540 $\mathrm{nm}$ and $690 \mathrm{~nm}$ on a 96 well plate reader (Multiskan Ascent, Thermo Electron Corporation, USA). The results are expressed as $\mathrm{IC}_{50}$ values (sample concentration which inhibited $50 \%$ of the net cell growth).

\section{SRB Assay}

This assay estimates cell number indirectly, by staining cellular protein with the protein-binding dye SRB (adapted procedure, by Skehan et al., 1990). After incubation, the cells were fixed adding cold $50 \%$ TCA and incubated for $1 \mathrm{~h}$ at $4{ }^{\circ} \mathrm{C}$. The wells were washed with deionised water and dried; SRB solution $(0.4 \%$ in $1 \%$ acetic acid) was then added to each plate well and incubated for $30 \mathrm{~min}$ at room temperature. The unbound SRB was removed by washing with $1 \%$ acetic acid. The plates were air dried, the bound SRB was solubilized with $10 \mathrm{mM}$ Tris $(\mathrm{pH}=$ 10.5), while absorbance was measured at $492 \mathrm{~nm}$ and $690 \mathrm{~nm}$, using the microplate reader. DMSO was applied as a positive control. The results are expressed as $I_{50}$ values.

\section{Data analysis}

The absorbance was calculated from the difference of two absorbances: $A=A_{540}$ $A_{690}$ and $=A_{492}-A_{690}$ for MTT and SRB assays, respectively. Percentage of cytotoxicity was calculated as the ratio of the treated and the control group absorbance respectively, multiplied by 100 . The obtained results are expressed as $I_{50}$. These values were calculated from the cytotoxicity (\%) - extract concentration plot $(\mu \mathrm{g} / \mathrm{ml})$ using the Origin v. 6.0 graphing and data analysis software (1999).

\section{Statistical analysis}

All the assays were carried out in triplicate. The data were statistically analyzed using the software Statistica (2013). The results of antioxidant and antiproliferative activities as well as total phenol (TP) and flavonoid (TF) contents are expressed as a mean value \pm standard deviation (SD). The statistical significance was determined by analysis of variance (ANOVA), with Duncan's multiple range test as post hoc test. The Pearson correlation coefficients $\left(r^{2}\right)$ were calculated for TP, TF, FRAP and $\mathrm{IC}_{50}$ values for anti-DPPH ${ }^{\circ}$ and antiproliferative activities.

\section{RESULTS AND DISCUSSION}

\section{Antioxidant activity and total phenol and flavonoid contents}

Among the examined extracts, $\mathrm{IC}_{50}$ value of LycAq stood out $(46.56 \mu \mathrm{g} / \mathrm{ml})$ in DPPH. scavenging assay (Table 1). Interestingly, in both assays these extracts showed higher activities compared with the experimental data obtained for $L$. perlatum originating from Portugal and Turkey (Barros et al., 2008b; Sarikurkcu et al., 2015). While there was no significant difference in their TP contents, TF content of LycAq was more than three times higher (Table 1).

Table 1.

Antioxidant activity and total phenol and flavonoid contents of Lycoperdon perlatum extracts

\begin{tabular}{ccc}
\hline Antioxidant Assay & LycEtOH & LycAq \\
\hline DPPH $^{*}$ & $176.04 \pm 23.58^{\mathrm{a}}$ & $46.56 \pm 15.78^{\mathrm{b}}$ \\
\hline FRAP $^{\star \star}$ & $21.87 \pm 0.90^{\mathrm{a}}$ & $19.28 \pm 0.80^{\mathrm{a}}$ \\
\hline Total content $^{\star \star \star}$ & & \\
\hline TP & $1.92 \pm 0.01^{\mathrm{a}}$ & $1.96 \pm 0.05^{\mathrm{a}}$ \\
TF & $0.17 \pm 0.06^{\mathrm{b}}$ & $0.58 \pm 0.13^{\mathrm{a}}$
\end{tabular}

${ }^{\star}$ Expressed as concentration of the extracts that caused $50 \%$ activity $-1 C_{50}(\mu \mathrm{g} / \mathrm{ml})$. ${ }^{* *}$ Expressed as $\mathrm{mg}$ ascorbic acid equivalents/g extract of dry weight (mg AAE/g d.w.). ${ }^{* * *}$ Total phenol (TP) content is expressed as mg gallic acid equivalents/g extract of dry weight (mg GAE/g d.w.), while total flavonoid (TF) content is expressed as $\mathrm{mg}$ quercetin equivalents/g extract of dry weight ( $m g \mathrm{QE} / \mathrm{g}$ d.w.)

${ }_{a, b}$ The results are expressed as a mean value $\pm S D$. The means with different superscript within the same row are statistically different $(p<0.05)$ 
Table 2.

Antiproliferative activity of Lycoperdon perlatum extracts on MCF-7 cells

\begin{tabular}{|c|c|c|c|c|}
\hline \multirow{2}{*}{ Extracts } & \multicolumn{2}{|c|}{ MTT Assay* } & \multicolumn{2}{|c|}{ SRB Assay* } \\
\hline & $24 \mathrm{~h}$ & $72 \mathrm{~h}$ & $24 \mathrm{~h}$ & $72 \mathrm{~h}$ \\
\hline LycAq & $>900^{\mathrm{a}}$ & $417.31 \pm 17.17^{\mathrm{a}}$ & $327.86 \pm 10.54^{b}$ & $707.05 \pm 16.29^{\mathrm{a}}$ \\
\hline LycEtOH & $691.64 \pm 36.45^{\mathrm{D}}$ & $367.54 \pm 22.34^{\mathrm{a}}$ & $854.849 \pm 22.62^{\mathrm{a}}$ & $390.03 \pm 21.27^{b}$ \\
\hline Positive control (DMSO) & 78.24 & 78.01 & 261.10 & 179.10 \\
\hline
\end{tabular}

Table 3.

The Pearson correlation coefficients $\left(r^{2}\right)$ between TP/TF contents and observed bioactivity in antiproliferative (MTT and SRB) and antioxidant (DPPH and FRAP) assays

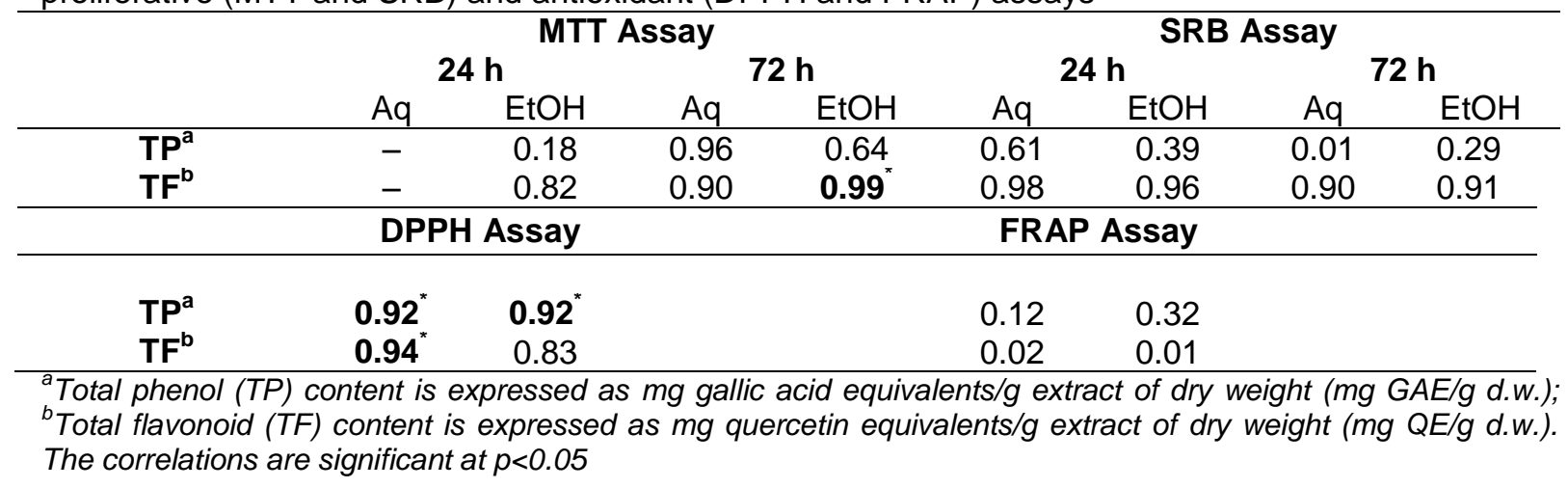

However, both extracts contained much lower TP and TF contents than etha$\mathrm{nol} /$ methanol extracts of the same fungal species collected in Slovenia and India, respectively $(\mathrm{TP}=34.56 \mathrm{mg} / \mathrm{g}$ and $\mathrm{TF}=$ $3.01 \mathrm{mg} / \mathrm{g}$; $\mathrm{TP}=6.25 \mathrm{mg} / \mathrm{ml}$ and $\mathrm{TF}=$ $2.52 \mathrm{mg} / \mathrm{ml}$; respectively) (Vidović, 2011; Ramesh and Pattar, 2010).

Taking into account both parameters (antioxidant activity and chemical composition), it may be assumed that phenolic and flavonoid compounds are not the only ones responsible for the observed activities.

\section{Antiproliferative activity}

The antiproliferative activity against human breast MCF-7 cancer cell-line was evaluated by MTT and SRB assays. The examined extracts (LycAq and LycEtOH) exhibited different activity in the aforementioned bioassays (Table 2). Generally, it was modest with $\mathrm{LycAq}\left(\mathrm{IC}_{50}=327.86\right.$ $\mu \mathrm{g} / \mathrm{ml}$ ) being the most potent one (SRB assay, $24 \mathrm{~h}$ ). As other bioactivities, this one also directly depends on the chemical composition (Table 2) (Houghton et al., 2007; Kaišarević, 2011).

Cinnamic acid, previously found in some puffball species, has been recently linked to growth inhibition of a lung cancer cell- line (Barros et al., 2009; Vaz et al., 2012). In addition, the current literature data suggest phenolic acids, steroids and triterpenoids as the key cytotoxic principles of the puffballs (Waser, 2002; Ferreira et al., 2010; De Silva et al., 2013).

The Pearson correlation coefficient $\left(r^{2}\right)$ between TP/TF contents and this activity in both applied assays (Table 3 ) pointed out much higher values for TF (in a narrow range, from 0.82 to 0.99 , with the only one being statistically significant - LycEtOH in MTT assay, 72h) than TP content (in a wider range, from 0.18 to 0.96 , with no statistical significance). The same correlations for antioxidant activity (Table 3 ) indicated TP/TF content significance only for anti-DPPH radical activity. The other phenolics including phenolic acids could be responsible for demonstrated antioxidant activities according to previous literature data (Karaman et al., 2010; Karaman et al., 2014; Ferreira et al., 2009). The observed chelating ability is likely to be linked to other classes of organic compounds (found in some mushroom species) such as polysaccharides, proteins and terpenic acids. Actually, the further research is expected to clarify this particular issue (Kalogeropoulos et al., 2013). 
Table 4.

Antibacterial activity of Lycoperdon perlatum hexane extract

\begin{tabular}{lcc}
\hline Bacterial Strain & MIC $^{*}$ & MBC $^{*}$ \\
\hline Escherichia coli ATCC 25923 & $>25$ & $>25$ \\
Staphylococcus aureus ATCC 25922 & 3.12 & 6.25 \\
Bacillus subtilis ATCC 6633 & $>25$ & $>25$ \\
\hline Antibiotics & 2.50 & 10.00 \\
\hline Gentamicin** $(\mu \mathrm{g} / \mathrm{ml})$ & 8.00 & 128.00 \\
Ampicillin ${ }^{* *}(\mu \mathrm{g} / \mathrm{ml})$ &
\end{tabular}

\section{Antibacterial activity}

LycHex practically displayed a modest antibacterial activity only against the strain S. aureus ATCC 25922 (MIC $=3.12$ $\mathrm{mg} / \mathrm{ml}, \mathrm{MBC}=6.25 \mathrm{mg} / \mathrm{ml}$ ) (Table 4). These results are in good accordance with recently published data for the same puffball species collected in India (Ramesh and Pattar, 2010).

\section{CONCLUSIONS}

L. perlatum, the examined fungal species in this study, may be considered as a promising source of novel natural antioxidants with potential significance for regular diet. If its autochthonous origin is taken into account, this fact is even more important. Puffball species in Serbia have not been examined enough so far. To our knowledge, this is the first report on bioactivity of the autochthonous species $L$. perlatum. The future research work should be primarily directed towards elucidation of chemical profiles of LycAq and LycEtOH and their mechanism(s) of action.

\section{ACKNOWLEDGEMENTS}

This study was supported by the Ministry of Education, Science and Technological Development of the Republic of Serbia (Research grants No. III 46001, OI 172058 and OI 172053) and the Provincial Secretariat for Science and Technological Development (Research grant No. 114451-1112/2014-03).

\section{REFERENCES}

1. Alves, M. J., Ferreira, I. C., Froufe, H. J., Abreu, R. M. V., Martins, A., Pintado, M. 2013. Antimicrobial activity of phenolic compounds identified in wild mushrooms, SAR analysis and docking studies. Journal of Applied Microbiology, 115 (2), 346-357.
2. Bandow, J. E., Brötz, H., Leichert, L. I. O., Labischinski, H., Hecker, M. 2003. Proteomic approach to understanding antibiotic action. Antimicrobial Agents and Chemotherapy, 47 (3), 948-955.

3. Barros, L., Cruz, T., Baptista, P., Estevinho, L. M., Ferreira, I. C. 2008a. Wild and commercial mushrooms as source of nutrients and nutraceuticals. Food and Chemical Toxicology, 46 (8), 2742-2747.

4. Barros, L., Dueñas, M., Ferreira, I. C., Baptista, P., Santos-Buelga, C. 2009. Phenolic acids determination by HPLC-DAD-ESI/MS in sixteen different Portuguese wild mushrooms species. Food and Chemical Toxicology, 47 (6), 1076-1079.

5. Barros, L., Venturini, B. A., Baptista, P., Estevinho, L. M., Ferreira, I. C. 2008b. Chemical composition and biological properties of Portuguese wild mushrooms: a comprehensive study. Journal of Agricultural and Food Chemistry, 56 (10), 3856-3862.

6. Benzie, I. F., Strain, J. J. 1999. [2] Ferric reducing/antioxidant power assay: Direct measure of total antioxidant activity of biological fluids and modified version for simultaneous measurement of total antioxidant power and ascorbic acid concentration. Methods in Enzymology, 299, 15-27.

7. Chang, C. C., Yang, M. H., Wen, H. M., Chern, J. C. 2002. Estimation of total flavonoid content in propolis by two complementary colorimetric methods. Journal of Food and Drug Analysis, 10 (3), 178-182.

8. Cheung, P. C. K. 2010. The nutritional and health benefits of mushrooms. Nutrition Bulletin, 35 (4), 292-299.

9. De Silva, D. D., Rapior, S., Fons, F., Bahkali, A. H., Hyde, K. D. 2012. Medicinal mushrooms in supportive cancer therapies: an approach to anti-cancer effects and putative mechanisms of action. Fungal Diversity, 55 (1), 1-35.

10. De Silva, D. D., Rapior, S., Sudarman, E., Stadler, M., Xu, J., Alias, S. A., Hyde, K. D. 2013. Bioactive metabolites from macrofungi: ethnopharmacology, biological activities and chemistry. Fungal Diversity, 62(1), 1-40.

11. Dickinson, C. H., Lucas, J. A. 1982. VNR color dictionary of mushrooms. Van Nostrand Reinhold, New York.

12. Espín, J. C., Soler-Rivas, C., Wichers, H. J. 2000. Characterization of the total free radical 
scavenger capacity of vegetable oils and oil fractions using 2, 2-diphenyl-1-picrylhydrazyl radical. Journal of Agricultural and Food Chemistry, 48 (3), 648-656.

13. Ferreira, I. C., Barros, L., Abreu, R. 2009. Antioxidants in wild mushrooms. Current Medicinal Chemistry, 16 (12), 1543-1560.

14. Heleno, S. A., Ferreira, I. C., Calhelha, R. C., Esteves, A. P., Martins, A., Queiroz, M. J. R. 2014. Cytotoxicity of Coprinopsis atramentaria extract, organic acids and their synthesized methylated and glucuronate derivatives. Food Research International, 55 (1), 170-175.

15. Houghton, P., Fang, R., Techatanawat, I., Steventon, G., Hylands, P. J., Lee, C. C. 2007. The sulphorhodamine (SRB) assay and other approaches to testing plant extracts and derived compounds for activities related to reputed anticancer activity. Methods, 42 (4), 377-387.

16. Kaišarević, S. 2011. Ćelijski markeri toksičnosti kao integrisan signal nivoa kontaminacije perzistentnim organskim polutantima. Doktorska disertacija, Prirodno-matematički fakultet, Univerzitet u Novom Sadu.

17. Kalogeropoulos, N., Yanni, A. E., Koutrotsios, G., Aloupi, M. 2013. Bioactive microconstituents and antioxidant properties of wild edible mushrooms from the island of Lesvos, Greece. Food and Chemical Toxicology, 55, 378-385.

18. Karaman M., Kaišarević S., Somborski J., Kebert M., Matavulj, M. 2009a. Biological activities of the lignicolous fungus Meripilus giganteus (Pers.: Pers.) Karst. Archives of Biological Sciences, 61(4), 853-861.

19. Karaman M., Stahl M., Vulić J., Vesić M., Čanadanović-Brunet, J. 2014. Wild-growing lignicolous mushroom species as sources of novel agents with antioxidative and antibacterial potentials. International Journal of Food Sciences and Nutrition, 65 (3), 311-319.

20. Karaman, M., Jovin, E., Malbaša, R., Matavulj, M., Popović, M. 2010. Medicinal and edible lignicolous fungi as natural sources of antioxidative and antibacterial agents. Phytotherapy Research, 24 (10), 1473-1481.

21. Karaman, M., Mimica-Dukic, N., Knezevic, P., Svircev, Z., Matavulj, M. 2009b. Antibacterial properties of selected lignicolous mushrooms and fungi from northern Serbia. International Journal of Medicinal Mushrooms, 11 (3), 269279.

22. Lamotte, J., Oleksyn, B., Dupont, L., Dideberg, O., Campsteyn, H., Vermeire, M., RhugendaBanga, N. 1978. The crystal and molecular structure of 3-[(5S)-5-carboxy-2-oxotetrahydrofur-5-yl]-(2S)-alanine (lycoperdic acid). Acta Crystallographica Section B: Structural Crystallo-graphy and Crystal Chemistry, 34 (12), 3635-3638.

23. Miles, P. G., Chang, S. T. 2004. Mushrooms: cultivation, nutritional value, medicinal effect, and environmental impact. CRC press, Boca Raton, FL, USA.
24. Mosmann, T. 1983. Rapid colorimetric assay for cellular growth and survival: application to proliferation and cytotoxicity assays. Journal of Immunological Methods, 65 (1), 55-63.

25. Nwachukwu, E., Uzoeto, H. O. 2010. Antimicrobial activity of some local mushrooms on pathogenic isolates. Journal of Medicinal Plants Research, 4 (23), 2460-24655.

26. Ozen, T., Darcan, C., Aktop, O., Turkekul, I. 2011. Screening of antioxidant, antimicrobial activities and chemical contents of edible mushrooms wildly grown in the Black Sea region of Turkey. Combinatorial Chemistry \& High Throughput Screening, 14 (2), 72-84.

27. Patel, S., Goyal, A. 2012. Recent developments in mushrooms as anti-cancer therapeutics: a review. 3 Biotech, 2 (1), 1-15.

28. Pujol, V., Seux, V., Villard, J. 1990. Research of antifungal substances produced by higher fungi in culture. Annales Pharmaceutiques Francaises, 48 (1), 17-22.

29. Ramesh, C., Pattar, M. G. 2010. Antimicrobial properties, antioxidant activity and bioactive compounds from six wild edible mushrooms of western ghats of Karnataka, India. Pharmacognosy Research, 2 (2), 107-112.

30. Sarikurkcu, C., Tepe, B., Kocak, M. S., Uren, M. C. 2015. Metal concentration and antioxidant activity of edible mushrooms from Turkey. Food Chemistry, 175, 549-555.

31. Singleton, V. L., Orthofer, R., Lamuela-Raventos, R. M. 1999. [14] Analysis of total phenols and other oxidation substrates and antioxidants by means of folin-ciocalteu reagent. Methods in Enzymology, 299C, 152-178.

32. Skehan, P., Storeng, R., Scudiero, D., Monks, A., McMahon, J., Vistica, D., Boyd, M. R. 1990. New colorimetric cytotoxicity assay for anticancer-drug screening. Journal of the National Cancer Institute, 82 (13), 1107-1112.

33. STATISTICA (Data Analysis Software System) (2013), version 12.0. StatSoft Inc., Tulsa, OK, USA (www.statsoft.com)

34. Szumny, A., Adamski, M., Winska, K., Maczka, W. 2010. Identification of steroid compounds and essential oils from Lycoperdon perlatum. Przemysl Chemiczny, 89 (4), 550-553.

35. Vaz, J. A., Almeida, G. M., Ferreira, I. C., Martins, A., Vasconcelos, M. H. 2012. Clitocybe alexandri extract induces cell cycle arrest and apoptosis in a lung cancer cell line: identification of phenolic acids with cytotoxic potential. Food Chemistry, 132 (1), 482-486.

36. Wasser, S. 2002. Medicinal mushrooms as a source of antitumor and immunomodulating polysaccharides. Applied Microbiology and Biotechnology, 60 (3), 258-274.

37. Westh, H., Zinn, C. S., Rosdahl, V. T. 2004. An international multicenter study of antimicrobial consumption and resistance in Staphylococcus aureus isolates from 15 hospitals in 14 countries. Microbial Drug Resistance, 10 (2),169176. 


\section{УВИД У IN VITRO БИОАКТИВНОСТ САМОНИКЛЕ ПУХАРЕ LYCOPERDON PERLATUM (PERS) 1796}

Александра Р. Новаковић ${ }^{1 *}$, Маја А. Караман ${ }^{2}$, Милан Н. Матавуљ ${ }^{2}$, Борис М. Пејин ${ }^{3}$, Миона М. Беловић ${ }^{1}$, Тања И. Радусин ${ }^{1}$, Небојша М. Илић $^{1}$

${ }^{1}$ Универзитет у Новом Саду, Научни институт за прехрамбене технологије, Булевар цара Лазара 1, 21000 Нови Сад, Србија

${ }^{2}$ Универзитет у Новом Саду, Природно-математички фракултет, Департман за биологију и екологију, Трг Доситеја Обрадовића 3, 21000 Нови Сад, Србија

${ }^{3}$ Универзитет у Београду, Институт за мултидисциплинарна истраживања (IMSI), Одсек за науке о живим системима, Кнеза Вишеслава 1, 11030 Београд, Србија

Сажетак: Lycoperdon perlatum (Pers) 1796 је сапробна пухара са широком распрострањеношћу. Јестива је као млада, када је глеба још целовита и бела. Због пријатне текстуре и укуса, користи се у супама, као замена за кнедле. Циљ овог рада био је да се проучи биоактивност сирових екстраката врсте L. perlatum припремљених од самониклих спорокарпа пореклом из источне Србије (Сиколе, село близу Неготина) током 2012. године.

Скрининг биоактивности обухватио је антиоксидативну (тестови DPPH• и FRAP), антипролиферативну (ћелијска линија хуманог аденокарцинома дојке, MCF-7; тестови MTT и SRB) и антибактеријску активност (три референтна АТСС соја; микродилуциони тест). Поларнији екстракти испитиване гљиве (водени - LycAq и етанолни - LycEtOH) тестирани су на антиоксидативном и антитуморском нивоу, док је неполаран екстракт (LycHex) тестиран на антибактеријском нивоу. Осим тога, LycAq и LycEtOH хемијски су прелиминарно окарактерисани (садржај укупних френола и флавоноида) помоћу UV-VIS спектрофотометрије.

Највећа анти-DPPH радикалска активност уочена је за $\mathrm{LycAq}\left(\mathrm{IC}_{50}=46.56 \mu \mathrm{g} / \mathrm{ml}\right)$. У поређењу са LycAq, мање поларни екстракт LycEtOH показао је незнатно бољи потенцијал за редукцију гвожђа $\left(\mathrm{IC}_{50}=21.87 \mu \mathrm{g} / \mathrm{ml}\right.$ и $\left.\mathrm{IC}_{50}=19.28 \mu \mathrm{g} / \mathrm{ml}\right)$. Међутим, садржај укупних френола у оба екстракта био је сличан ( $\approx 2.0 \mathrm{mg} \mathrm{GAE} / g . d . w$.$) . С друге стране, крајње блага антибактеријска$ активност уочена је на сој Staphylococcus aureus ATCC 25922 (LycHex, MIC = $3.12 \mathrm{mg} / \mathrm{ml}$ ) и ћелије MCF-7 (уз најзначајнију активност за LycEtOH након $72 \mathrm{~h}, \mathrm{IC}_{50}=367.54 \mu \mathrm{g} / \mathrm{ml}$ и $\mathrm{IC}_{50}=$ $390.03 \mu \mathrm{g} / \mathrm{ml}$, на тестовима MTT и SRB).

Према добијеним експерименталним подацима, L. perlatum може се сматрати добрим извором нових и потентних природних антиоксиданаса са потенцијалном применом у редовној исхрани.

Кључне речи: пухара, Lycoperdon perlatum, биолошка активност, природни антиоксиданси, лековита храна

Received: 7 April 2015

Accepted: 31 May 2015 